\title{
CSF and plasma GABA levels in Parkinson's disease
}

\author{
RJ ABBOTT, IF PYE, SR NAHORSKI* \\ From the Department of Neurology, Leicester Royal Infirmary, and the Department of Pharmacology \\ and Therapeutics, ${ }^{*}$ University of Leicester, Leicester, UK
}

SUMMARY CSF gamma-aminobutyric acid (GABA) levels were reduced in patients with idiopathic Parkinson's disease when compared with age matched controls, but the difference was not significant. However, when the Parkinsonian patients were subdivided, CSF GABA levels were lower in the levodopa treated group than in the untreated group and the controls. There was no difference in plasma GABA levels between Parkinsonian patients and controls.

In the early stages of idiopathic Parkinson's disease, the major pathology lies in the substantia nigra where there is degeneration of dopaminergic cells. The resulting deficiency of dopamine in the corpus striatum leads to hypokinesis and rigidity, symptoms which frequently respond to therapy with levodopa. However, some patients fail to respond to levodopa and others obtain symptomatic improvement with anticholinergic therapy alone, suggesting that other neurotransmitter systems may be implicated in the pathophysiology of Parkinson's disease.

Dopaminergic nigrostriatal neurones are under tonic feedback control via strionigral pathways which use GABA as their neurotransmitter. ${ }^{1}$ Abnormalities of both pre-synaptic and post-synaptic components of GABAergic systems have been described in Parkinson's disease. ${ }^{2}$ CSF GABA levels are thought to reflect changes in central GABA neurotransmission ${ }^{4}$ and have the advantage over post-mortem tissue studies that they can be studied during life, and at different stages in the natural history of the disease. In addition, CSF GABA may be a better index than tissue GABA of that fraction of the amino acid released as transmitter, rather than just forming part of the overall metabolic pool.

We report here CSF GABA levels in two groups of patients in whom Parkinson's disease was at different stages, and compare the findings with those of an age matched control group.

Address for reprint request: Dr RJ Abbott, Senior Registrar in Neurology, St James's University Hospital, Beckett Street, Leeds LS9 7TF, UK.

Received 8 July 1981 and in revised form 29 September 1981 Accepted 3 October 1981

\section{Patients}

Control Patients (Group A). Patients in the 40-70 yr age group who underwent diagnostic lumbar puncture and were subsequently found to have no evidence of structural neurological disease were used as controls. These were predominantly patients with symptoms but no abnormal physical signs (table).

Parkinsonian Patients (Groups $B$ and $C$ ). Patients with Parkinson's disease were divisible into two clinically different groups (table). In the first were patients who had received no levodopa therapy (Group B). In the second were patients who had developed the late complications which are associated with advanced disease and chronic levodopa therapy (Group C). Clinical disability in the Parkinsonian patients was assessed according to self care ability as graded on the Webster rating scale. Examination of the two groups showed that the patients treated with levodopa had suffered from Parkinson's disease for longer and were much more disabled than the untreated patients.

\section{Methods}

CSF GABA levels were measured using a radioreceptor assay modified slightly from the technique previously described. $^{5}$ The CSF was collected by lumbar puncture in a standardised manner. The first $5 \mathrm{ml}$ of CSF were sent for routine analysis and the subsequent $5 \mathrm{ml}$ collected on ice in separate $1 \mathrm{ml}$ aliquots. The specimens were deep frozen at $-70^{\circ} \mathrm{C}$ within 10 minutes of collection and kept deep frozen until assay. These strict precautions are necessary to prevent artefactual elevation of GABA levels which is known to occur in CSF exposed to room temperature. ${ }^{6}$ Venous blood was obtained immediately following lumbar puncture and plasma GABA levels estimated using the same technique. Statistical analysis of the results was performed using Student's $t$ test. 
Table

\begin{tabular}{|c|c|c|c|c|c|c|c|}
\hline & No & $\begin{array}{l}\text { Mean age } \\
(y r s)\end{array}$ & $\operatorname{Sex}$ & Diagnosis & & & \\
\hline Control group & 15 & $52 \cdot 1$ & $\begin{array}{l}12 \text { Male } \\
3 \text { Female }\end{array}$ & $\begin{array}{l}\text { 6. Tension } \\
\text { 3. Non sp } \\
\text { 1. Tinnitu } \\
\text { 2. Facial } \\
\text { 1. BIH } \\
\text { 2. Hysteri }\end{array}$ & $\begin{array}{l}\text { /A } \\
\text { ific dizzines }\end{array}$ & & \\
\hline \multicolumn{8}{|c|}{ Parkinsonian patients } \\
\hline & \multirow[t]{2}{*}{ No. } & \multirow{2}{*}{$\begin{array}{l}\text { Mean age } \\
(y r s)\end{array}$} & \multirow[t]{2}{*}{$\operatorname{Sex}$} & \multicolumn{2}{|l|}{ Disease } & \multicolumn{2}{|c|}{ L-Dopa therapy } \\
\hline & & & & Severity & $\begin{array}{l}\text { Duration } \\
\text { (yrs) }\end{array}$ & Duration & $\begin{array}{l}\text { Daily dosage } \\
\text { (mgs) }\end{array}$ \\
\hline Untreated & \multirow[b]{2}{*}{13} & \multirow[b]{2}{*}{$56 \cdot 8$} & 7 Male & 3 Mod & \multirow[b]{2}{*}{$1 \cdot 8$} & \multirow[b]{2}{*}{-} & \multirow[b]{2}{*}{-} \\
\hline Group (B) & & & 6 Female & 10 Mild & & & \\
\hline Treated & \multirow[b]{2}{*}{13} & \multirow[b]{2}{*}{$62 \cdot 3$} & 5 Male & 6 Severe & \multirow[b]{2}{*}{$5 \cdot 3$} & \multirow[b]{2}{*}{$3 \cdot 9$} & \multirow[b]{2}{*}{661} \\
\hline Group (C) & & & 8 Female & 7 Mod & & & \\
\hline
\end{tabular}

\section{Results}

CSF GABA levels were lower in the Parkinsonian patients $(189.5 \pm 113.7 \mathrm{pmol} / \mathrm{ml}$; mean $\pm \mathrm{SD}$, $\mathrm{n}=26)$ than in controls $(265.5 \pm 119.5 \mathrm{pmol} / \mathrm{ml}$; $\mathrm{n}=15$ ), but the difference was not significant. However, there was a lower mean CSF GABA in the treated patients $(159.1 \pm 77.7 \mathrm{pmol} / \mathrm{ml} ; \mathrm{n}=13$, $\mathrm{p}<0.02)$, but not in the untreated group $(219.9 \pm$ $137.5 \mathrm{pmol} / \mathrm{ml} ; \mathrm{n}=13$ ) (fig $1 \mathrm{~A}$ ) compared to controls. In addition, the mean CSF GABA concentration was lower in the treated compared with the untreated Parkinsonian patients $(p<0.02)$. This trend was confirmed in two patients in whom CSF GABA levels were measured immediately before and again three months after commencing levodopa therapy; CSF GABA levels fell from 520 to 300 $\mathrm{pmol} / \mathrm{ml}$ in one patient and from 390 to $285 \mathrm{pmol} / \mathrm{ml}$ in the other. Plasma GABA levels were not different in either treated $(575.0 \pm 136.8 \mathrm{pmol} / \mathrm{ml} ; \mathrm{n}=6)$, or untreated $(472 \cdot 8 \pm 157 \cdot 5 \mathrm{pmol} / \mathrm{ml} ; \mathrm{n}=7)$ Parkinsonian patients compared with controls $(583.3 \pm$ $180 \cdot 4 \mathrm{pmol} / \mathrm{ml} ; \mathrm{n}=6$ ) (fig 1B).

\section{Discussion}

GABA does not cross the blood brain barrier and it is not surprising that changes in GABA within the brain are not reflected in the plasma. Early studies of CSF GABA levels in Parkinson's disease showed conflicting results, ${ }^{7} 8$ but these did not take account of the clinical status of the patients studied. Manyam et $a l^{9}$ reported lower CSF GABA levels in untreated patients compared to those who had received levodopa. Teychenne et al $l^{10}$ initially reported no differences relating to clinical status, but have subsequently found low CSF GABA levels in patients who respond poorly to levodopa and those with the "on-off" phenomena, but normal GABA concentrations in patients who respond well to levodopa. ${ }^{11}$

Our study confirms the finding of low CSF GABA concentrations in patients who have developed the problems associated with advanced disease and long term levodopa therapy. In contrast, patients with early Parkinson's disease who have not received levodopa have normal CSF GABA levels. Our finding of reduced CSF GABA concentrations in Group $\mathrm{C}$ may be a direct consequence of levodopa therapy itself, and the sequential study in two patients supports this hypothesis. However, animal studies have shown that prolonged oral administration of levodopa does not alter CSF GABA levels in rats. ${ }^{12}$ An alternative explanation of this finding may relate to the more advanced stage of the disease in the treated patients in whom neuronal degeneration may be more widespread, and the low CSF GABA may be due to a reduction in the number of functioning GABAergic neurons. Finally it might be argued that the reduction in GABA turnover is merely a secondary phenomenon resulting from reduced dopaminergic activity in the degenerating nigrostriatal pathway.

CSF GABA levels have previously been shown to be reduced in elderly females. ${ }^{13}$ Over the narrow age range of patients involved in this study there is no correlation of CSF GABA levels with age, but in all the subgroups studied the mean value for females in the group is lower than for males (fig 1A). Although there was a preponderance of females in the treated Parkinsonian group, the CSF GABA concentration in both males and females in this group is lower than in equivalent patients in groups $\mathbf{A}$ and B. Therefore it would appear that the observation of 


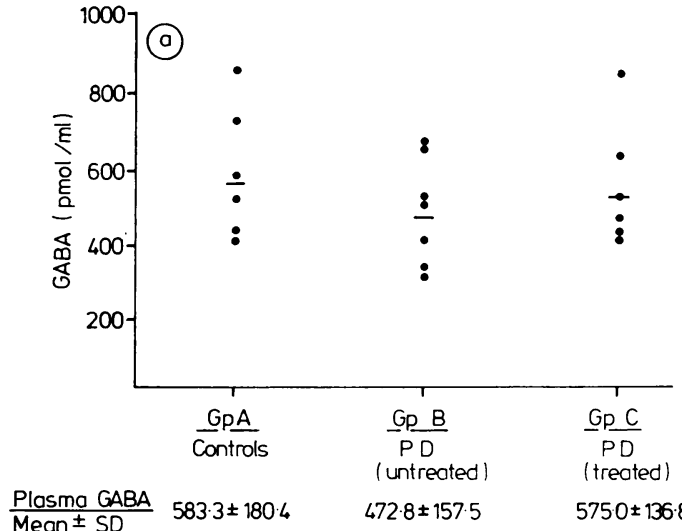

suggests that drugs which enhance GABA neurotransmission may be of value in the treatment of levodopa induced dyskinesias. Baclofen, ${ }^{14}$ sodium valproate ${ }^{15}$ and $\mathrm{SL} 6002^{16}$ have all shown little benefit in this respect, but newer, and possibly more selective GABAergic drugs, may soon become available.

We gratefully acknowledge the help of Dr PAH Millac who allowed us to study his patients and supplied helpful advice and criticism.

\section{References}

${ }^{1}$ Yoshida M, Precht W. Monosynaptic inhibition of neurones of the substantia nigra by caudatonigral fibres. Brain Res $1971 ; 32: 225-8$.

${ }^{2}$ McGeer PL, McGeer EG, Wada JA. Glutamic acid decarboxylase in Parkinson's Disease and epilepsy. Neurology (Minneap) $1971 ; 21: 1000-7$.

${ }^{3}$ Lloyd KG, Shemen L, Hornykiewicz O. Distribution of high affinity sodium independent ${ }^{3} \mathrm{H}-\mathrm{GABA}$ binding in the human brain: alteration in Parkinson's Disease. Brain Res 1977;127:269-78.

${ }^{4}$ Bohlen P, Huot S, Palfreyman MG. The relationship between GABA concentrations in brain and cerebrospinal fluid. Brain Res 1979;167:297-305.

${ }^{5}$ Abbott RJ, Nahorski SR. A radioreceptor assay using ${ }^{3} \mathrm{H}$-muscimol for GABA in human cerebrospinal fluid. Br J Pharmacol 1981;72:164.

${ }^{6}$ Grossman MH, Hare TA, Manyam NVB, Glaeser BS, Wood JH. The stability of GABA levels in CSF under various conditions of storage. Brain Res 1980;182:99-106.

' Lakke TPW, Teelken AW. Amino-acid abnormalities in cerebrospinal fluid of patients with Parkinsonian and extrapyramidal disorders. Neurology (Minneap) 1976;26:489-93.

${ }^{8}$ Enna SJ, Stern LZ, Wastek GJ, Yamamura HI. Cerebrospinal fluid gamma-aminobutyric acid variations in neurological disorders. Arch Neurol 1977; 37:352-5.

${ }^{9}$ Manyam NVB, Katz L, Hare TA, Grossman MH. Levels of gamma-aminobutyric acid in cerebrospinal fluid in various neurologic disorders. Arch Neurol 1980;34:683-5.

${ }^{10}$ Teychenne PF, Lake CR, Ziegler MG. In: Wood JH, ed. Neurobiology of cerebrospinal fluid. New York: Plenum Press, 1980;197-206.

low CSF GABA levels in Group C, compared to the other groups, is independent of age or sex differences.

With regard to therapy it seems unlikely that drugs which enhance GABA neurotransmission will be of value in the treatment of Parkinson's disease, since they antagonise dopaminergic function and will tend to exacerbate the symptoms of hypokinesis and rigidity. However the findings of low CSF GABA concentrations in patients who are experiencing dyskinetic side effects related to levodopa therapy

11 Teychenne PF, Ziegler MG, Lake CR, Enna SJ. Low CSF GABA in Parkinsonian patients who respond poorly to therapy or suffer from the on-off phenomenon. Neurology (Minneap) 1981;31:134 (Abst).

12 Wilner KD, Butler JJ, Seifert WE, Clement Cormier YC. Biochemical alterations of dopamine receptor responses following chronic levodopa therapy. Biochem Pharmacol 1980;29:701-6.

${ }^{13}$ Hare TA, Wood JH, Manyam NVB, Ballenger JC, Post RM, Gerner RH. Selection of control populations for clinical cerebrospinal fluid GABA investi- 
gations based on comparison with normal volunteers. Brain Res Bull 1980;5.Supp 2:721-4.

${ }^{14}$ Lees AJ, Shaw KM, Stern GM. Baclofen in Parkinson's Disease. J Neurol Neurosurg Psychiatry 1978;41: 707-8.

15 Price $P$, Parkes JD, Marsden CD. Sodium valproate in the treatment of levodopa-induced dyskinesia. J Neurol Neurosurg Psychiatry 1978;41:702-6.

${ }^{16}$ Sheehy MP, Schachter M, Parkes JD, Marsden CD. In: Rose FC, Capildeo R, eds. Research progress in Parkinson's Disease. Kent: Pitman Medical, 1981; 309-17. 